and Wales, or that the Bretton Woods conference was about nutrition. Twice the author enjoys herself in vigorous passages exposing the dangers inherent in a Civil Service composed of an intellectual élite the members of which are so imbued with loyalty and integrity in relation to a system, which, in return, gives them security, that they neglect the moral and intellectual obligation to follow the truth wherever it leads.

To write a sustained work relating three such ill. defined but important subjects as social biology, social welfare and social philosophy needs a remarkably well-ordered mind and exceptional literary skill. Mrs. Neville-Rolfe's gifts are more those of a crusader than of a writer; her enthusiasm and courage have played an influential part in freeing consideration of sex relationships in their social aspect from the taboos which hindered either biological or social scientists from tackling the subject so recently as forty years ago. The weakness of her book does not diminish the debt owed to her and her like by the inquiring scientific mind.

ROGER WILSON<smiles>C1C[GeH2]1</smiles>

\section{THE BRITISH WILD FLORA}

\section{Introduction to Wildflowers}

By Richard Mprof Pp. $266+48$ plates. (London : Adam and Cha ples Black, Ltd., 1949.) 12s. 6d. net. R ICHARW MORSE'S latest book is described as $R$ "a sfople, readable introduction to the study of Britsh wildflowers". This unpretentious claim is justifie thy the book itself, which, in clear and nontechincal language, shows how flowers may be identified, how they live, behave and reproduce. The book is arranged in two parts. Part 1 contains an account of some of the more interesting families of British wildflowers, which are always referred to by their common names, botanical names being omitted. This half of the book has been deliberately planned to draw the new reader on and on without upsetting his supposed dislike for technical terms. Part 2 has been written to supplement Part $I$ and contains a short synopsis of all the families of British flowering plants, Latin names being included. It also contains sections giving the numerical distribution of wildflowers, their usual habitats and the seasons at which they appear as well as a section in which wild flowers are arranged according to their colour. A wellarranged bibliography is included as a valuable appendix, and there are also four indexes giving English and Latin names to individual flowers and to the families to which they belong, with the necessary cross-references.

At first sight the arrangement of this book is confusing; but closer acquaintance shows that, for the elementary reader he has in mind, Morse has produced a book which should achieve his purpose. For the reader with a little knowledge of wild flowers and no particular dread of Latin names-many authors of wide experience believe that these, in fact, attract the inquiring beginner much more than they repel-the frequent journeys to the rear of the book for further information may be somewhat irritating and scarcely necessary.

The outstanding feature of the illustrations are the thirty-two photographs, some of which are of unusual quality as black-and-white reproductions. The line-drawings are clear, and there are sixteen colour plates.

T. H. H.

\section{DEVELOPMENT OF SOCIOLOGY}

Societal Evolution 816

A Study of the Evolutionary Basis of the Science of Society. By Prof. Arthur Galloway Keller. Revised edition. Pp. ix +419. (New Haven, Conn.: Yale University Press; London: Oxford University Press, 1947.) 21s. net.

An Introduction the History of Sociology Edited by farfy Elmer Barnes. Pp. xvi+960. (Chicago: Unversity of Chicago Press; London: Cambridge University Press, 1948.) 55s. net.

A MERI:AN sociology has now a long and honour$A$ Ale history behind it; the vitality which it sheus at the present time is in large measure due to the sundness of the foundations that have been laid drchg the past half-century. The time has, indeed, now arrived when some of the outstanding classic works should be re-published, and for a general appraisal to be made of the work that has been achieved by the earlier pioneers.

A good example of a work that has been too easily overlooked in Great Britain is Prof. A. G. Keller's "Societal Evolution". This was originally produced in 1915 ; in the edition of 1931 which is now re. printed, it is both a memento of a young and vigorous period in the development of American sociology, and also a demonstration of the way in which Summer's approach to the problem of social change was extended by Prof. Keller, his disciple and successor at Yale. The ideas embodied in it may perhaps strike the younger sociologist of to-day as somewhat naive; for the evolutionary theories of both Spencer and Summer have been rejected as, at best, a gross over-simplification of the problem. Nevertheless, the content of the subject of sociology has been largely determined by the range of interests of the classic authors, particularly by their exploitation of the rich territory of ethnology, and it has been shown to be possible to separate the 'automatic' theory of social evolution from the evidence which was adduced in support of these views. The work of Summer's school, therefore, still endures in part, and the present generation of sociologists would do well to treat what is perhaps "the most forceful American statement of the evolutionary basis of individualism and laissezfaire" with due respect.

The above quotation is from "An Introduction to the History of Sociology", edited by Harry Elmer Barnes. This is an exceedingly useful work of reference; but it is no mere collection of 'points of view' or 'contributions' by various authors and schools of thought. As the editor points out, it is high time that an appraisal should be attempted of the various 'systems' of sociology which have appeared from the time of Comte to the present day, for systematization is now being gradually but completely "replaced by specialization in some more restricted field of description and analysis" ; in brief, "the era of systematic sociology has come approximately to an end".

Whether or not this will involve a retreat to an 'ivory tower', built on new lines, time alone will show. If, however, sociology is successfully developed as a tool to serve man's needs rather than as an elegant but useless subject of study, it will only be because our critical powers have been fully employed in the task. Mr. Barnes's penetrating survey of the past is therefore a most useful aid to the shaping of a new science on 'operational' rather than 'philosophical' lines. 